\title{
Nature and Place of Crime Scene Management within Forensic Sciences
}

Author : Frank Crispino, PhD, MPhil

\section{Introduction}

Since the early $90 \mathrm{~s}$, criminologists have begun to question the nature of everyday forensic science practices [1-10], and this obviously has consequences for its related ethics and deontology [11-14]. It appears that the 1993 US Daubert hearing not only challenged the nature of the various fields of forensic science [15-17] but also our understanding of the nature of evidence. This had already been confronted by the development of DNA analysis [18]. Moreover it also challenged the concept of forensic science as being a unified whole, by invoking Popper's falsificationist epistemology as being the only relevant criteria for accepting a body of knowledge as science. [19] As the 'crime scene' is the basis of the subsequent interpretation of evidence, Inman and Rudin affirm that Locard's Principle was unable to be tested, and as such was metaphysical, and hence not 'scientific' in the US Supreme Court terms influenced by Popper. This almost removed all scientific character from later professional practice.

On the other hand, both the scientific methodology defended, for instance, by criminologists such as Tuthill, Bevel or Wertheim, [21-23] and the reasoning process, seem powerless [24, 25], if not irrelevant $[26,27]$ in allowing us to defend the higher philosophical level of forensic science, without taking into account the process of the management of the crime scene. Moreover, although recognising the importance of crime scene examination within forensic science, a recent paper downplayed the importance of qualifying it as scientific, even claiming that its reliance on inductive rather than deductive reasoning meant it could not be said to be 'truly scientific' [28].

This new interest in the true nature of our full body of knowledge requires not only a better understanding of the logic of science, but also shows the need to break down the constraints provided by believing that inductivism and deductivism are the only available scientific approaches. 
I - The present state of epistemology: is Popper the only available philosophical criteria to define sciences?

The Daubert hearing required courts to focus only on the fundamental principles of applied science and on its related methodology to allow it to understand the scientific nature of expert knowledge $[20,29]$. It almost calls to mind the three 'levels' which constitute science, with the Principles or Fundamental Ideas at the top, Applied Methodology underneath and the Technical Tools at the bottom $[15,30,31]$. The Daubert case asks us to question our understanding of the upper level of science, remembering that repetitive and comparative methods do not guarantee the scientific nature of knowledge, as can be seen in astrology, witchcraft or Adlerian psychology. As an aside, do not theological universities, generally considered as belonging to the world of metaphysics, sometimes declare themselves to be engaged in scientific research, embracing even forensic science [32] ?

It may be better to remind ourselves of the evolutionary nature of the philosophical concepts of science, leading to rational criticism as being the baseline of today's western scientific culture. The pathway from an antiquarian anthropocentrist perception of the world - at that time perceived as scientific - to a positivist understanding of our environment - which is why it is called 'natural science' - leaves traces about our understanding of the external world, which itself has consequences for our thinking processes and our contemporary empirical methodology.

As Aristotelicism insists that deductivism is the only possible scientific process, relying on accepted premises issued from an inductive intuition, its scholastic application, which refused to question the Biblical truths of the Revelation, allowed western science to flounder until the $15^{\text {th }}$ century. At this time, the only academic study at the time was in relation to God, and the natural world could only be considered in that context. This was not challenged until the discoveries and research of Copernicus (1473 - 1543) and Galileo (1564 - 1642), and this created 200 years of academic 
turbulence. Descartes (1596 - 1650) was the first philosopher not to challenge deductivism, but to seek fundamental principles not arising from religious certainties but from a personal questioning of oneself. This would lead to a logical pathway which itself would lead back to God. This logical construction of the world, finding support in practical observation, does not protect us from conceptual fallacies such as the Vortex Theory, where the sun would be at the centre of a large whirlwind where planets and satellites swirl around a centre.

At the same time, Sir Francis Bacon $(1561$ - 1626) proposed that no underlying theory was needed to observe and interpret nature, with knowledge being merely the result of experience [33]. Even if this completely inductivist approach at the macro level contributed to the advance of the British Industrial Revolution with its mechanical advances, its application at the daily new discovered telescopic and microscopic levels let David Hume (1711 - 1776) demonstrate that induction is unable to be the basis of a general law [34].

Within rationalism, which tries to construct an underlying structure on which to build scientific knowledge [35-37], it has to be admitted that the Fundamental Principles are only hypotheses [38, 39], for which invariant relations between observations allow us to predict phenomenological occurrences supporting an imaginary, but accepted law, thus defining the positivist approach of Auguste Comte (1798 - 1897). The incredible success of this philosophy seems to be supported by the then 200 year old physicist theory of Newton. It is not surprising that a logical normalisation of this philosophy was developed by a collection of philosophers and scientists within the so-called logical positivist Vienna school, which would have led to a Universal Theory of Knowledge during the first half of the $20^{\text {th }}$ century. This was at a time when Newton's theory was finally proved incorrect by the successful prediction by Einstein of the curvature of rays of the sun during the 1919 eclipse.

This event allowed Karl Raymund Popper (1902 - 1994) to develop his own falsificationist 
epistemology of knowledge, where our certainties can only be negative: we can only be sure of a theory which does not work, never of a one which does work, which can only be labelled as 'not yet falsified'. Hence, science is the body of knowledge relying on principles which are able to be tested for falsification, i.e. on which we can create experiments to try to prove them wrong [40-42].

Anachronisms in Popper's explanation of the historical progress of science, and difficulties in distinguishing the absence of controls from tests for falsification led even Popper to soften his falsificationist philosophy, and opened the door to his contradictors as early as the 1960s [26, 4346]. This is not the place to explain their epistemological proposals, but it is better to record that the Daubert hearing focused on an epistemology which was highly criticised in the 90s, and was qualified by Popper himself as irrelevant for a full set of knowledge, tackling or including sociological data as forensics obviously does, if crime is considered as a sociological fact [47].

Today, a syncretic Popper-Kuhn neo-experimentalist epistemology requires a better understanding of control factors in experiments through an iterative optimisation process, before testing their fundamental principles for falsification [48-54]. Applied to forensic science, this approach requires a better understanding of the SOCO's ${ }^{1}$ working conditions including their reasoning processes to increase the chance of finding traces, i.e. optimisation of Locard's Principle, before testing it for falsification.

\section{II - Deduction, induction and abduction as the true nature of human reasoning.}

The complexity of human reasoning, permanently shifting between different kinds of induction and deduction, sometimes does not allow for an oversimplification of human thinking between an alternative deduction/induction duality [55]. Moreover, this limitation of the thinking process does not allow us to recognise that even induction was not really defined before the $19^{\text {th }}$ century, as it

1 The 'Scenes of Crime Officer'. 
indiscriminately covered a direct logical empirical generalisation of fact by reason or by systematic experimentation. Newton himself defined it as a phenomenological deduction, meaning a logical consequence of scientific conclusions from repetitive occurrences [56]. Thus, when induction is used by Descartes, Kant, Newton or Sherlock Holmes, can we be sure they mean the same thing?

If we make an effort better to distinguish between these thinking processes we are able to propose that deduction can produce the results of a pure hypothesis in which truth is not questioned, as induction only tests an hypothesis, which would be accepted by the (single or repeated) observations of facts, considered at the time to be true. Hence, figure 1 explains that induction is the only thought process able to issue a general law through scrutiny of the initial situation and subsequent observations, as deduction derives observations from these initial conditions under a general law, which cannot be questioned. This thinking process induces a third undetected process called abduction [37] : abduction is an unsound basis from which to develop explanatory initial conditions to match accepted theory with observations [57, 58]. It infers the initial conditions derived from an accepted general law and 'a posteriori' observations. To summarise: deduction proves that something should happen, induction shows something is happening, and abduction suggests that something could be happening. 


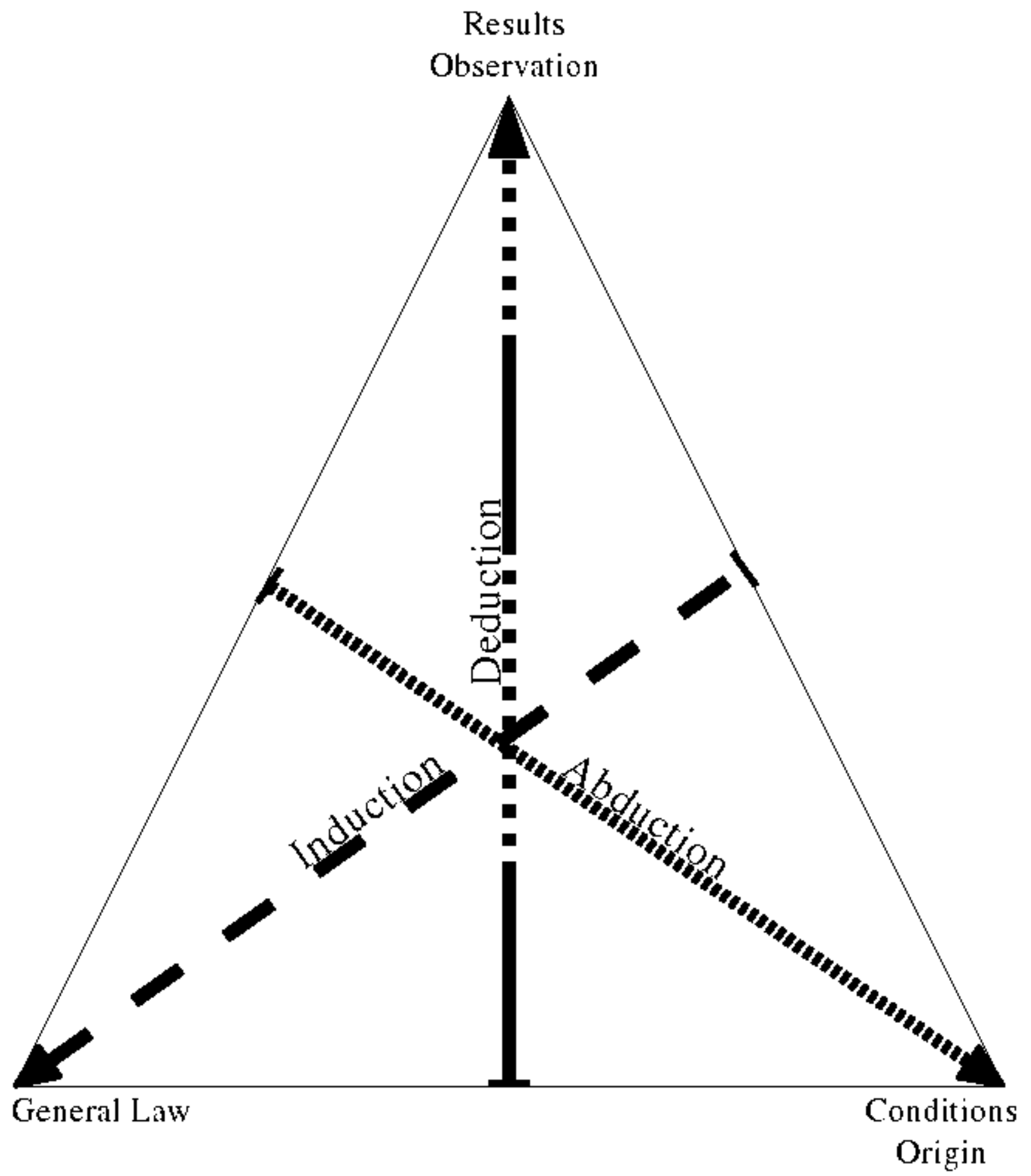

Figure $1:$ Inferences schematisation

It should be understood that abduction, like deduction and induction, is only an inference, as simple, as solid and as natural as the other two. It is the thousand year old reasoning process of the hunter acquiring the art of detecting animals through trace observation [59], analogous of the tasks of the investigator and criminologist [60]. It is as formal and mechanical as the other inferences, with a 
conclusion as logically strong. It is neither a more original nor a more inventive process than the processes of deduction or induction, and it would be difficult to claim that one of them is psychologically easier or more difficult than the others [61]. The scientifically accepted hypothetico-deductive method $[62,63]$, when applied to crime scene investigation looks, in the absence of question about Locard's Principle, like a set of deduction and abduction shuttle processes.

Finally, how can it be claimed that deductive inference is more scientific, as progress in science would have been impossible without some risk being taken during the development of a new theoretical hypothesis through induction supported by abduction leading to the establishment of a general law? This would be simply impossible through pure deduction alone.

\section{Conclusion}

It is understandable that the epistemological approach still represents a challenge for our forensic community, as a major and unchallengeable characteristic of criminalitics, not shared with other sciences, is its interest in individualisation. Whilst other sciences incline towards taxonomical classification, our science wants to link any unidentified evidence or item to a unique source [64]. This is also what the bringing-together of so many disparate forensic fields: biological, ballistic, chemical, human traces, nuclear, radiological, engineering, etc... relies on.

If we are ready to leave our 'pre-scientific' status to enter into a 'scientific' one, we shouldn't be afraid to question our fundamental principles through a recognised philosophical strategy, which would not only fully define our daily practice as scientists, but also recognise crime scene management as belonging to this forensic group, because it is the fundamental building block of this undoubtedly natural science. 
Acknowledgement.

The author wishes to thank Dr Paul Swallow, the British Counter-Terrorism Liaison Officer in Paris, for his deep involvement with the writer in translating this short typically French cartesian brainstorming session into an improved form of English.

Bibliography

[1] Hoke F., Science in the Courtroom : What Evidence is Admissible - And Who Decides?, The Scientist Vol 8(12), 1994, 1, 4-5.

[2] Zimmerman J., The "What If" Hypothesis, Int. J. Forensic Doc. Exam. 3(3), 1997, 225-228.

[3] Grieve D.L., Rocking the Cradle, Journal of Forensic Identification 49(6), 1999, 719-727.

[4] Grieve D.L., Simon Says, Journal of Forensic Identification 51(1), 2001, 85-97.

[5] Sturner W.Q., Herrmann M.A., Boden C., Scarrit T.P. Jr, Sherman R.E., Harmon T.S., Woods K.B., The Frye Hearing in Florida : An Attempt to Exclude Scientific Evidence, Journal of Forensic Sciences, JFSCA 45(4), 2000, 908-910.

[6] Kaufman H.H., The Expert Witness. Neither Frye nor Daubert Solved the Problem: What Can Be Done ?, Science \& Justice 41(1), 2001, 7-20.

[7] Zlotnick J., Lin J.R., Handwriting Evidence in Federal Courts - From Frye to Kumho, Forensic Science Review 13, 2001, 87-98.

[8] Pretty I.A., Sweet D., The Scientific Basis for Human Bitemark Analyses - A Critical Review, Science \& Justice 41(2), 2001, 85-92.

[9] McDonald A., Battles are Won in the Temples, Journal of Forensic Identification, JFI 52(4), 2002, 397-399.

[10] Morton E.A., Emergency !, Journal of Forensic Identification, JFI 52(3), 2002, 250-251.

[11] Evett I.W., Criminalistics: the Future of Expertise, Science \& Justice 33(3), 1993, 173-178.

[12] Robertson B., Vignaux B.A., Interpreting Evidence. Evaluating Forensic Science in the Courtroom, John Wiley \& Sons Inc., New York, NY, USA, 1995.

[13] Evett I.W., Expert Evidence and Forensic Misconceptions of the Nature of Exact Science, Science \& Justice 36(2), 1996, 118-122.

[14] Kind S.S., The Sceptical Witness, Hodology, London, 1999.

[15] Faigman D.L., Porter E., Saks M.J., Check Your Crystal Ball at the Courthouse Door, Please : Exploring the Past, Understanding the Present, and Worrying About the Future of Scientific Evidence, Cardozo Law Review, Vol. 15, 1994.

[16] Saks M.J., Implications of the Daubert Test for Forensic Identification Science, Shepard's Expert \& Scientific Evidence, Vol 1(3), 1994, 427-434.

[17] Saks M.J., Merlin and Solomon: Lessons from the Law's Formative Encounters with Forensic Identification Science, Hastings Law Journal, Vol. 49, 1998, 1069-1141.

[18] Saks M.J., Koehler J.J., What DNA "Fingerprinting" Can Teach the Law About the Rest of Forensic Science, CARDOZO Law Review, Vol. 13, 1991, 361-372.

[19] US Supreme Court No. 92-102, William Daubert, al., Petitioners v Merrell Dow Pharmaceuticals, Inc. Certiorari to the U.S. Court of Appeals for the Ninth Circuit, argued March 30, 1993 - Decided June 28, 1993.

[20] Inman K., Rudin N., Principles and Practice of Criminalistics - The Profession of Forensic Science, CRC Press, Boca Raton, FL, USA, 2001.

[21] Tuthill H., Individualization : Principles and Procedures in Criminalistics, Lightning Powder Co., Jacksonville, FL, USA, 1994.

[22] Bevel T., Applying the Scientific Method to Crime Scene Reconstruction, Journal of Forensic Identification 51(2): 150-162, 2001. 
[23] Wertheim K., Re: ACE-V : Is It Scientifically Reliable and Accurate ?, Journal of Forensic Identification 52(6), 2002, 669-677.

[24] Chalmers A.F., La fabrication de la science, Editions de la découverte, Paris, 1990.

[25] Chalmers A.F., What Is This Thing Called Science ?, 3rd edition, Hackett Publishing Co., Indianapolis, IN, USA, 2000.

[26] Feyerabend P., Farewell to Reason, Verso, London, 2000a.

[27] Eco U., Kant et l'ornythorynque, Le livre de poche, Paris, 1999.

[28] Harrison K., Is Crime Scene Examination science, and does it matter anyway ?, Science \& justice 46(2), $65-68,2006$.

[29] US District Court for the Eastern District of Pennsylvania, US vs Byron Mitchell Daubert Hearing Documents, Criminal N96-00407, 1999.

[30] Whewell W., Novum Organon Renovatum, Book II of the Construction of Science, in Butts R.E., Ed. Theory of Scientific Method, Hackett Publishing Company, Inc., Indianapolis, IN, USA, 1858 (1989).

[31] Butts R.E., Ed., Theory of Scientific Method, Hackett Publishing Company, Inc., Indianapolis, IN, USA, 1989.

[32] Forrest R., Wither Academic Forensic Science ?, Science \& Justice 44(4), 2004, 195.

[33] Bacon F., The New Organon, Cambridge University Press, UK, 1620 (2000).

[34] Hume D., Enquête sur l'entendement humain, GF Flammarion, Paris, 1758 (1983).

[35] Kant E., Critique de la raison pure, GF Flammarion, Paris, 1781 (2001).

[36] Whewell W., Remarks on Mathematical Reasoning and on the Logic of Induction, in Butts

R.E., Ed. Theory of Scientific Method, Hackett Publishing Company, Inc., Indianapolis, IN, USA, 1989, 33 - 53, 1837 (1989).

[37] Peirce C.S., La première règle de la logique, in Le raisonnement et la logique des choses, Editions du Cerf, Paris, 1898 (1995).

[38] Poincaré H., La science et l'hypothèse, Flammarion, Paris 1902 (1991).

[39] Poincaré H., La valeur de la science, Flammarion, Paris, 1905 (1991).

[40] Popper K.R., La logique de la découverte scientifique, Bibliothèque scientifique Payot, Paris, 1973.

[41] Popper K.R., Conjectures et réfutations - La croissance du savoir scientifique, Payot, Paris, 1985.

[42] Popper K.R., La connaissance objective, Champs - Flammarion, Paris, 1991.

[43] Kuhn T., La structure des révolutions scientifiques, Champs - Flammarion, Paris, 1970.

[44] Kuhn T., The Essential Tension, University of Chicago, IL, USA, 1977.

[45] Kuhn T., Logic of Discovery or Psychology of Research in Criticism and the Growth of Knowledge, Lakatos I., Musgrave A., ed., Cambridge University Press, UK, 1999.

[46] Feyerabend, Against Method, Verso, London, 2000b.

[47] Crispino F., Le principe de Locard est-il scientifique ? Ou analyse de la scientificité des principes fondamentaux de la criminalistique, thèse de doctorat, institut de police scientifique de l'Université de Lausanne, 2006.

[48] Hacking I., Representing and Intervening, Cambridge University Press, UK, 1983.

[49] Ackermann R.J., Data, Instruments, and Theory : A Dialectical Approach to Understanding Science, Princeton University Press, Princeton, NJ, USA, 1985.

[50] Franklin A., The Neglect of Experiment, Cambridge University Press, UK, 1986.

[51] Franklin A., Experiment, Right or Wrong, Cambridge University Press, UK, 1990.

[52] Giere R.N., Explaining Science : A Cognitive Approach (Science and Its Conceptual Foundations), University of Chicago Press, Chicago, IL, USA, 1990.

[53] Galison P.L., How Experiments End, University of Chicago Press, Chicago, IL, USA, 1992.

[54] Mayo D., Error and the Growth of Experimental Knowledge, The University of Chicago Press, IIL, USA, 1996.

[55] George C., Polymorphisme du raisonnement humain. Une approche de la flexibilité de l'activité inférentielle, Presses Universitaires de France, Paris, 1997. 
[56] Nickles T., Discovery, in Companion to the History of Modern Science, Olby R.C., Cantor G.N., Christie J.R.R., Hodge M.J.S., ed., Routledge, London, 1996.

[57] Harrowitz N., The Body of the Detective Model. Charles S. Peirce and Edgar Allan Poe, in Dupin, Holmes, Peirce The Sign of Three, 198 - 220, Eco U., Sebeok T.A., ed., First Midland Book Edition, Indiana University Press, IN, USA, 1998.

[58] Sebeok T.A., Umiker-Sebeok J., "You Know My Method" : A Juxtaposition of Charles S. Pierce and Sherlock Holmes, in Dupin, Holmes, Peirce The Sign of Three, 11 - 54, Eco U., Sebeok T.A., ed., First Midland Book Edition, Indiana University Press, IN, USA, 1988.

[59] Ginzburg C., Clues : Morelli, Freud, and Sherlock Holmes, in Dupin, Holmes, Peirce The Sign of Three, 81 - 118, Eco U., Sebeok T.A., ed., First Midland Book Edition, Indiana University Press, IN, USA, 1988.

[60] Zeleznikow J., The Split-Up Project : Induction, Context and Knowledge Discovery in Law, Law, Probability and Risk (3), 2004, 147 - 168.

[61] Bonfanti M.A., Prodi G., To Guess or Not to Guess, in Dupin, Holmes, Peirce The Sign of Three, 119 - 134, Eco U., Sebeok T.A. Ed., First Midland Book Edition, Indiana University Press, IN, USA, 1988.

[62] CHISUM J., An Introduction to Crime Scene Reconstruction in TURVEY B., Criminal Profiling - An Introduction to Behavioral Evidence Analysis, Academic Press, New York, NY, USA, 1999.

[63] KWAN Q.Y., Inference of Identity of Source, Dissertation, Thesis for the Doctorat in Criminology, Berkeley University, CA, USA, 1976.

[64] Nicol J.D., The Bachelor of Sciences in Criminalistics (program brochure), University of Illinois, Chicago, IL, USA, 1972. 